\title{
The Governance of Wetlands in the Tonle Sap Lake,
}

\section{Cambodia}

\author{
Mak Sithirith \\ Department of Natural Resource Management and Development, Royal University of Phnom Penh, Russian Federation Boulevard, \\ Phnom Penh 12101, Cambodia
}

\begin{abstract}
Cambodia is a country where wetlands cover 30\% of the country's total area. The Tonle Sap Lake is an important wetland area of Cambodia and Southeast Asia. However, wetland is under threats from infrastructure development, land conversion, water withdrawals, pollution, increased population pressure and hydropower dams building and affect the livelihoods of rural communities. The governance of wetlands is a key action in sustaining the wetland services and the well-being of people. The "wise use" is a key concept of wetland governance. Although there is considerable research on the "wise use" and the application of this concept in wetland management, its application in Tonle Sap remains challenged. Hence, this article addresses the question: How wise use is operationalized for the governance of wetlands in Tonle Sap and what implication it has on the wellbeing of peoples and the ecosystem services? It uses a literature review and a case study to analyze the wetland governance in Tonle Sap, Cambodia. The article describes the wetland governance based on ecosystem services, the direct and indirect driver affecting wetlands and how it threatens the livelihood security of wetland dependent communities. It concludes that the officially wise use of wetlands is a problematic in Tonle Sap.
\end{abstract}

Key words: Wetland, ecosystem services, wise use, well-being, decision-making, distribution of power, accountability.

\section{Introduction}

Cambodia is a country where wetlands represent over $30 \%$ of the total area and it is rich in wetland resources [1]. The Tonle Sap Lake, Mekong River and Bassac River are the three largest freshwater wetland regions in the country. The Tonle Sap Lake is one of three international Ramsar sites recognized by the Ramsar conventions. Wetlands are lands transitional between terrestrial and aquatic systems where the water table is usually at or near the surface or the land is covered by shallow water [2]. Human societies are fundamentally linked to wetlands, from the core human requirements for water and food to the choices and trade-offs they make and the governance systems that influence their behaviors in and around wetlands. Central to appreciating wetland is that humans are part of ecosystems, not separate from them.

Corresponding author: Mak Sithirith, Ph.D., senior lecturer, research fields: environmental and resource governance. E-mail: mak.sithirith@rupp.edu.kh.
Eventually, wetland worldwide is under threats from infrastructure development, land conversion, water withdrawals, pollution and increased population pressure. Global climate changeand nutrient loading are projected to become increasingly important drivers. Increased human use of fresh waterhas reduced the amount available to maintain the ecological character of many inland water systems. Throughout the world, the construction of dams has changed flow regimes, changed the transport of sediments and nutrients, modified habitat and disrupted migration routes of aquatic biota such as salmon. With population growth and the over exploitation and contamination of water resources, the gap between available water and water demand is increasing in many parts of the world.

The degradation and loss of wetland have affected the livelihoods of wetland's dependent communities. In both rural and urban areas, the poor are likely to suffer most when the availability and quality of water 
and food are reduced, whether due to failures in infrastructure and trade networks or to the demise of wetlands. The declining condition of wetlands has placed their ecosystem services and the people who depend on them at increasing risk.

Thus, the governance of wetlands is the key to sustain the wetland services and the well-being of people. The literature on governance of wetlands refers to the "wise use of wetlands" as a key governance principle. The "wise use of wetlands" is defined as "the maintenance of ecological character, achieved through the implementation of ecosystem approaches, within the context of sustainable development", which in turn, emphasizes the value of wetlands to people through the delivery of ecosystem service. The ecological character is defined as the "combination of the ecosystem components, processes and benefits/services that characterize the wetland at a given point in time". Wetland ecosystems provide a diversity of servicesvital for human well-being: provisioning, regulating, supporting and cultural services $[3,4]$. Thus, the "wise use" equates to the maintenance of ecosystem benefits/services is to ensure long term maintenance of biodiversity as well as human well-being and poverty alleviation [3].

Wetland ecosystems and the services which they provide form an integral part of the livelihood strategy of wetland-dependent communities. Their livelihood systems often involve adapting to the overall ecological character of the wetland so as to optimize livelihood outcomes. Similarly, livelihood strategies of communities living in and around wetlands also influence their ecological character. Change in ecological character is the human-induced adverse alteration of any ecosystem component, process, and/or ecosystem benefit/service [4].

The capability to access and use wetland resources is influenced by institutional arrangements, structures and processes, policies, laws and other norms. Institutions facilitate governance and/or control over the use of wetlands at the household and community levels $[4,5]$. It facilitates a process of empowerment of stakeholders to ensure their rights in relation to resources as they are involved in decision-making. It is a process that implies the sharing of power through institutional processes and structures for equitable decision-making in wetland management [5]. The study given by the governance of aquatic agricultural system, with study case in Tonle Sap, argued that the governance should focus on three distinct dimensions: the stakeholder representation (participation), distribution of authority and mechanism of accountability [6].

Stakeholder participation also contributes to the decision-making process because it provides a better understanding of impacts and vulnerability, the distribution of costs and benefits associated with trade-offs and the identification of a broader range of response options that are available in a specific context. Stakeholder participation at all stages of planning and development processes can assist decision-making concerning wetlands, particularly when considering the environmental water requirements of wetlands $[3,7,8]$. As wetlands become scarcer and the benefits provided by the entire array of ecosystem services become degraded, the stakeholder participation is increasingly essential in ensuring that the wetland ecosystem services remain serving the well-being of peoples. This requires participation of stakeholders in the maintenance of the wetland ecological character-the ecosystem components and processes that underpin the delivery of ecosystem services. Maintenance of the ecological character of wetlands will ensure that existing services continue to be delivered for the benefits of wetland's dependent communities $[3,8,9]$.

Distribution of authority determines the degree to which different institutions and actors share powers and responsibilities, and participate in managing wetland resources sustainably. The participation promotes the collaboration and cooperation among actors working on wetland governance [3]. Good governance and collaboration among institutions 
underpins the successful implementation of all response options for maintaining or restoring the ecological character of wetlands. Good governance and institutions, the political and legal mandates provide underpin the successful implementation of all response options $[8,10]$.

Accountability mechanisms determine the strength of accountability in multiple directions and influence the just distribution of wetland benefits [3,5]. A major shift in policy and decision making is required to incorporate the principles of consultation and transparency. Furthermore, ensure the long-term future of the services provided and supported by wetlands. Increased transparency and accountability of government and private-sector performance in decisions that affect wetlands, including through greater involvement of concerned stakeholders in decision-making is important element of wetland governance. Laws, policies, institutions and markets that have been shaped through public participation in decision-making are more likely to be effective and perceived as just if these actors are accountable and transparent in the management of wetlands. Stakeholder involvement and transparency of decision-making can increase accountability and reduce corruption $[3,8]$.

The management of ecosystem services cannot be sustainable if the growth in consumption of services continues unabated. Responses also need to address the enabling conditions that determine the effectiveness and degree of implementation of the wetland-focused actions. In particular, changes in institutional and environmental governance frameworks are often required to create these enabling conditions. Today's institutions were not designed to take into account the threats associated with the loss and the degradation of ecosystem services. Issues of ownership and access to resources, rights to participation in decision-making and regulation of particular types of resource use or discharge of wastes can strongly influence the sustainability of ecosystem management and are fundamental determinants of who wins and who loses from changes in ecosystems. Corruption, a major obstacle to effective management of ecosystems also stems from weak systems of regulation and accountability $[3,8]$.

A key approach for safeguarding the ecological character is to maintain the quantity and quality of the water on which wetlands depend. The effective management of inland wetlands and water resources will require improved arrangements for river (or lake or aquifer) basin. Greater coordination of actions among agreements would result in more-effective implementation. Because the benefits which improve stream flow and fresh water ecosystems are inherently public goods. Furthermore, the role of good governance and complete property rights for water remain fundamental enabling conditions for well-functioning markets.

\section{Method and Materials}

\subsection{Methods}

The article intends to move the above conceptual discussion forward and use it to analyze the wetland governance in Tonle Sap through a detailed examination of governance of land, water, fisheries, flooded forest and biodiversity in the lake. Thus, the wetlands governance of Tonle Sap is based on the management of fisheries, biodiversity and natural resources. Based on the diverse characteristics of wetlands governance, the framework for the discussion of wetlands governance in Tonle Sap is developed (Table 1). This paper analyzes the current Tonle Sap governance systems as well as the drivers, principles and policy framework for effective wetland management. First, this paper provides a general background on the Tonle Sap wetlands governance. Second, it analyzes the current wetlands governance system, focusing on how lake zoning shapes governance. Finally, the paper will examine how the human-nature relationship influences governance practice in the lake and in conclusion, will provide 
recommendations for improving future governance.

Data for this study were drawn from the Tonle Sap system, both at the macro and micro levels. The data were collected from around Kampong La community in Pursat Province, Kampong Phluk in Siem Reap Province and Peam Bang in Kampong Thom Province, Cambodia. Extensive field work at these sites was conducted between 2006 and 2010, with additional information gathered between April and May in 2013 and 2014 (Fig. 1). For this exploratory research, both qualitative and quantitative data were collected and analyzed. In terms of qualitative data, in-depth interviews and focus-group discussions were conducted. Alongside is a household survey using a questionnaire focused on household use of fish resources, the politics within the fishing communities and the conditions experienced by the fishers in each of the respective fishing industries.

\subsection{Tonle Sap and Wetland Ecological Characters}

The Tonle Sap Lake is the largest freshwater wetlands in Southeast Asia and is the seventh largest lake in the world in terms of size in the wet season [11, 12]. The length of the lake varies from approximately $160 \mathrm{~km}$ long [13] and $35 \mathrm{~km}$ wide (250,000-300,000 ha) during the dry season [14] to $250 \mathrm{~km}$ long and almost $100 \mathrm{~km}$ wide (1.0-1.3 million ha) during the peak flood in the wet seasons [15-17].

The Tonle Sap River connects the lake to the Mekong River. Tonle Sap absorbs a huge volume of water and helps reduce flooding in the Mekong River floodplain during the peak flooding season. It then releases water from the lake into the Mekong River during the dry season, helping to prevent salt intrusion into the Mekong Delta. This process is referred as the "flood pulse" [18-20] and it causes the lake to swell 5-6 times larger, with water level increasing from 1.5 $\mathrm{m}$ in the dry season to $9-10 \mathrm{~m}$ in the wet season [20].

Annually around 75,000 million $\mathrm{m}^{3}$ of surface water from the Mekong flows through Cambodia [22]. About 45,000 million $\mathrm{m}^{3}$ flows from the Mekong
River to Tonle Sap Lake [7]. Inflow consists of around $57 \%$ of the Tonle Sap water originates from the Mekong either through the Tonle Sap River (52\%) or overland flow (5\%), tributaries share $(30 \%)$ and precipitation (13\%) [23].

The Tonle Sap wetland is influenced by a "flood pulsed ecosystem" $[20,21,24]$. A term that is applied to the Lower Mekong based on research in other tropical river-floodplain systems [18, 25], which refers to the "pulsing ecosystem" [20]. The annual "flood pulse" (timing, modality, speed, height and duration) is of tremendous importance to fisheries productivity and fish migrations in the lower Mekong Basin and the Tonle Sap system [22, 26, 27]. The "flood pulse" transforms both the physical and the human landscape of the Lower Mekong and Tonle Sap, in which the flood water submerges the vast areas around the lake during the wet season, creating inundated forests with unique species adapted to the rhythms and cycles of the pulsing ecosystem and providing a wonderful habitat for many species of flora and fauna. In the dry season, the water recedes the lake and exposes the lake's areas to the dry condition. The Tonle Sap Lake provides habitats for approximately 280 fish species, 42-46 reptile species, 225 bird species and 15 mammal species [28, 29]. Moreover, it supports one of the most productive freshwater fisheries in the world, with annual yields of 230,000 tons which equivalent to approximately half of the country's total production [30].

This "flood pulse" in the Tonle Sap Lake has been compared to that of a heartbeat, with the flood pulse keeping the heart beating. This heartbeat is dependent on securing both the flow and volume of water. If the flow cannot be secured, reduces or stopped, there will not be enough volume to keep the heart beating. If the heart stops, the system dies [17] and the entire Mekong ecosystem would be adversely impacted, the fisheries would collapse, indigenous knowledge would be subverted, the poor would go hungry, livelihoods would be disrupted, local communities 


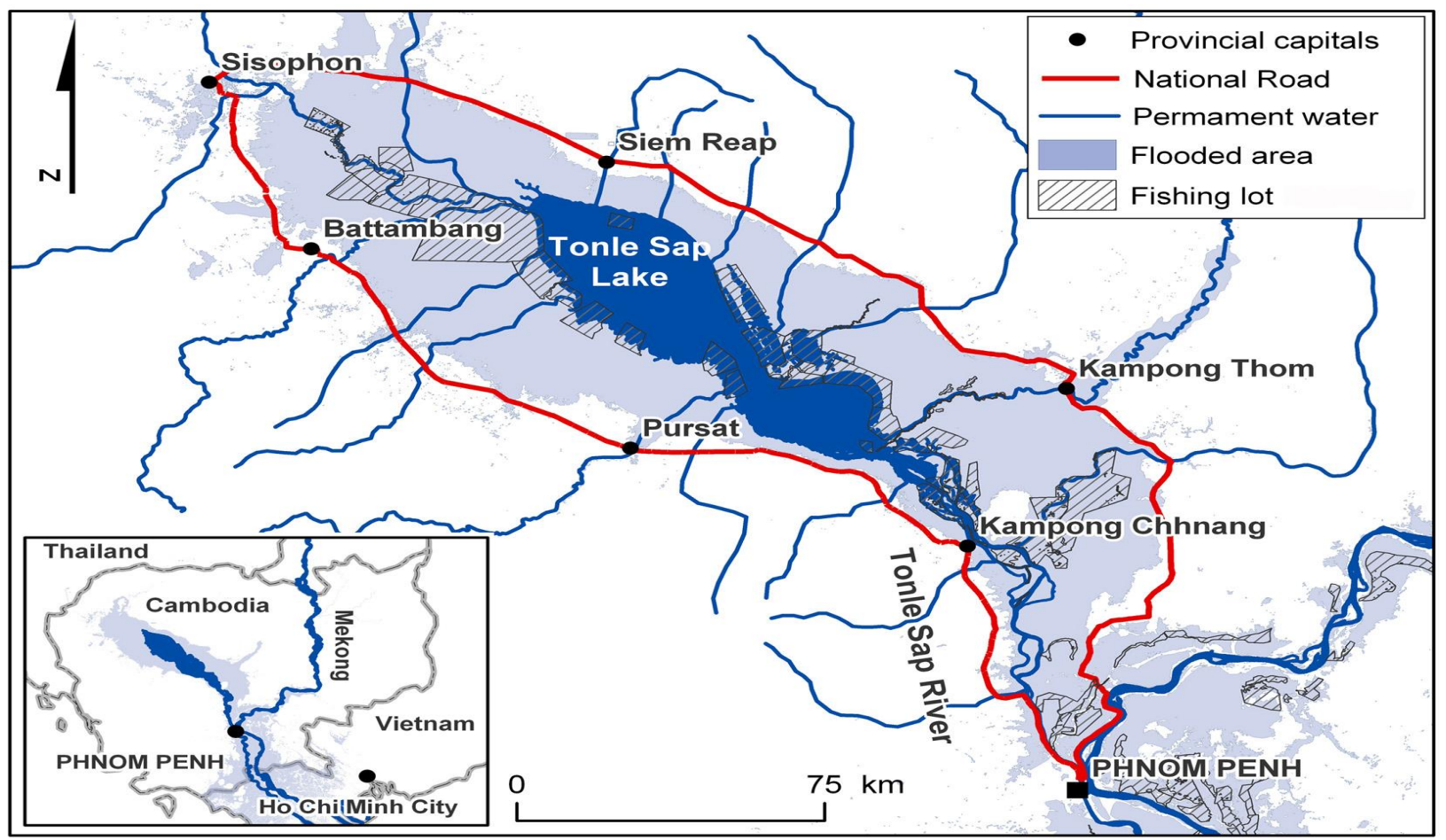

Fig. 1 Map of Tonle Sap lake.

would become dispossessed of their basic means of survival and the Cambodian economy would be severely affected $[17,20]$ (Table 1).

Commercial fishing, established in the early 1900's, controlled the Tonle Sap wetland governance system until 2012. Management was based upon a private property system in which the private businessman received exclusive rights to manage lake fishing through a public bidding process. Commercial fishing over-exploited fisheries resources and conflicted with small-scale fishing. The fishing competition between commercial and small-scale fishing operators has degraded fisheries resources, affecting fish, biodiversity and wetland resources damaging habitats for living organisms in the lake. This was a controversial and corrupt process which was abolished by the Royal Government of Cambodia (RGC) in early 2012. Fishing areas are now either open to public access or reserved for conservation. The question is asked how the cancelled fishing lot area in the Tonle Sap Lake is managed in the future.

China has built six dams on the Mekong's mainstream [31] while in the LMB, 12 hydropower dams have been proposed for the river's mainstream that could potentially displace 100,000 people, with 2.1 million others at risk of suffering indirect negative impacts [32]. The hydropower dams building in China, Laos, Thailand and Vietnam have altered the hydrological flow in the Mekong and Tonle Sap. Thus, larger areas of land around the Tonle Sap Lake is being flooded in the dry season, while in the wet season, only smaller land areas is flooded. This has affected the spawning grounds for fisheries, contributing to lowering the lake productivity and ecosystem services.

Furthermore, as the human population has increased over the past decades, the demand for resources provided by ecosystems increased over manifolds. Large area of flooded forest around the Tonle Sap Lake has encroached and converted into agricultural land. As a result, entire landscapes have been modified for human use and what remains is highly altered. Modern land-use changes have left us with altered ecosystem processes. 
Table 1 Zoning and governance of the wetlands in the Tonle Sap.

\begin{tabular}{|c|c|c|c|c|c|}
\hline \multirow{2}{*}{$\begin{array}{l}\text { Management } \\
\text { system }\end{array}$} & \multirow{2}{*}{\multicolumn{2}{|c|}{ Zoning (ha) }} & \multicolumn{3}{|c|}{ Dimensions of governance } \\
\hline & & & \begin{tabular}{|l|} 
Stakeholder \\
participation
\end{tabular} & Distribution of authority & $\begin{array}{l}\text { Mechanism of } \\
\text { accountability }\end{array}$ \\
\hline \multirow{4}{*}{$\begin{array}{l}\text { Fisheries and its } \\
\text { services }\end{array}$} & $\begin{array}{l}\text { Commercial fishing } \\
\text { area }\end{array}$ & $\begin{array}{l}\text { Commercial } \\
\text { fishing, but } \\
\text { recently } \\
\text { cancelled }\end{array}$ & $\begin{array}{l}\text { Large scale } \\
\text { fishing/private } \\
\text { FiA/government }\end{array}$ & $\begin{array}{l}\text { Absolute power of } \\
\text { fishing lot owners over } \\
\text { the fishing lot areas for } \\
2-4 \text { years }\end{array}$ & $\begin{array}{l}\text { Fishing lot owners } \\
\text { accountable to FiA }\end{array}$ \\
\hline & $\begin{array}{l}\text { Fish } \\
\text { sanctuary-24,680 ha } \\
\text { Fish } \\
\text { conservation-93,246 } \\
\text { ha }\end{array}$ & \begin{tabular}{|l|} 
Good fish \\
habitats, fish \\
stock areas, and \\
fish breeding \\
grounds \\
\end{tabular} & FiA & FiA & RGC \\
\hline & Public fishing area & $\begin{array}{l}\text { All people could } \\
\text { fish small and } \\
\text { medium scale } \\
\text { fishing }\end{array}$ & $\begin{array}{l}\text { Medium and } \\
\text { small-scale fishing }\end{array}$ & FiA & RGC \\
\hline & $\begin{array}{l}\text { Community fishery } \\
(\mathrm{CFi})-412,205 \text { ha }\end{array}$ & $\begin{array}{l}\text { Community } \\
\text { fishing areas }\end{array}$ & $\begin{array}{l}\text { Community based } \\
\text { fishery management, } \\
\text { but small-scale fishing }\end{array}$ & $\begin{array}{l}\text { Community still has no } \\
\text { power, but FiA remains } \\
\text { powerful }\end{array}$ & $\begin{array}{l}\text { CFi is accountable } \\
\text { to FiA, and less to } \\
\text { members. }\end{array}$ \\
\hline \multirow{3}{*}{$\begin{array}{l}\text { Biodiversity and its } \\
\text { services_biosphere } \\
\text { reserves }\end{array}$} & $\begin{array}{l}\text { Transition } \\
\text { zone-899,600 ha }\end{array}$ & $\begin{array}{l}\text { Residential } \\
\text { areas, } \\
\text { agriculture and } \\
\text { water }\end{array}$ & $\begin{array}{l}\text { MoE, MAFF, } \\
\text { MOWRAM, } \\
\text { UNESCO, FiA, local } \\
\text { government }\end{array}$ & $\begin{array}{l}\text { This area is not clearly } \\
\text { demarcated and it was } \\
\text { overlapped with the } \\
\text { former fishing lot areas } \\
\text { and areas that } \\
\text { communities use around } \\
\text { the lake }\end{array}$ & $\begin{array}{l}\text { MoE is responsible } \\
\text { for the management } \\
\text { of this area. }\end{array}$ \\
\hline & $\begin{array}{l}\text { Buffer zone-541,482 } \\
\text { ha }\end{array}$ & $\begin{array}{l}\text { Fisheries, } \\
\text { agriculture, } \\
\text { water, flooded } \\
\text { forest, wildlife }\end{array}$ & $\begin{array}{l}\text { MoE, UNESCO, } \\
\text { overlapping with FiA, } \\
\text { local government. }\end{array}$ & $\begin{array}{l}\text { MoE has the authority } \\
\text { over this area. This area } \\
\text { is allowed for } \\
\text { conservation plus some } \\
\text { development activities. }\end{array}$ & $\begin{array}{l}\text { MoE is responsible } \\
\text { for the management } \\
\text { of this area. This } \\
\text { area is not clearly } \\
\text { demarcated on the } \\
\text { ground. It overlaps } \\
\text { with the former } \\
\text { fishing lot areas. }\end{array}$ \\
\hline & Core zone $-42,257$ ha & $\begin{array}{l}\text { Fisheries, } \\
\text { wildlife, water, } \\
\text { flooded forest, } \\
\text { living space } \\
\end{array}$ & $\begin{array}{l}\text { MoE, UNESCO, } \\
\text { Ramsar }\end{array}$ & $\begin{array}{l}\text { MoE has the authority } \\
\text { over this area. }\end{array}$ & $\begin{array}{l}\text { MoE is responsible } \\
\text { for the management } \\
\text { of this area }\end{array}$ \\
\hline \multirow{3}{*}{$\begin{array}{l}\text { Flooded forests and } \\
\text { its services }\end{array}$} & $\begin{array}{l}\text { Zone 1: residential } \\
\text { zone-395,578 ha }\end{array}$ & $\begin{array}{l}\text { Residential } \\
\text { areas and } \\
\text { farming lands }\end{array}$ & $\begin{array}{l}\text { Community, local } \\
\text { government, provincial } \\
\text { Administration, TSA, } \\
\text { MOWRAM, MAFF, } \\
\text { MoE }\end{array}$ & $\begin{array}{l}\text { TSA, provincial } \\
\text { administration and } \\
\text { national government }\end{array}$ & $\begin{array}{l}\text { TSA is accountable } \\
\text { to higher level } \\
\text { government }\end{array}$ \\
\hline & $\begin{array}{l}\text { Zone 2: agricultural } \\
\text { development } \\
\text { zone-369,865 ha }\end{array}$ & $\begin{array}{l}\text { Farming land, } \\
\text { fishing areas, } \\
\text { flooded forest } \\
\text { (NTFPs), } \\
\text { Wildlife }\end{array}$ & $\begin{array}{l}\text { TSA, provincial } \\
\text { government, and local } \\
\text { government, } \\
\text { MOWRAM, MAFF, } \\
\text { MOE }\end{array}$ & $\begin{array}{l}\text { TSA has authority to } \\
\text { stop activities in this } \\
\text { area that could be } \\
\text { harmful to the flooded } \\
\text { forest or the } \\
\text { environment of the lake. }\end{array}$ & $\begin{array}{l}\text { TSA is accountable } \\
\text { to higher level } \\
\text { government }\end{array}$ \\
\hline & $\begin{array}{l}\text { Zone 3: flooded forest } \\
\text { zone- }-647,406 \text { ha }\end{array}$ & $\begin{array}{l}\text { Flooded forest } \\
\text { (NTFPs), } \\
\text { wildlife and } \\
\text { fisheries }\end{array}$ & $\begin{array}{l}\text { TSA, MOWRAM, } \\
\text { MAFF, FiA, MoE }\end{array}$ & $\begin{array}{l}\text { TSA prohibits any } \\
\text { activities in this area } \\
\text { that could damage the } \\
\text { flooded forest such as } \\
\text { clearance of flood forest } \\
\text { for agriculture, dikes, } \\
\text { canals, etc. }\end{array}$ & $\begin{array}{l}\text { TSA is accountable } \\
\text { to higher level } \\
\text { government }\end{array}$ \\
\hline
\end{tabular}




\section{Result and Discussion}

The Tonle Sap Lake, as a largest wetland area, provides arrays of ecosystem services to communities living around the lake including water, fisheries, agriculture, wildlife and other intangible services such as regulating flood, storms, siltation and salty intrusion. These services are categorized into provisioning, regulating, supporting and culture. Thus, the governance of wetland in Tonle Sap is equated as a governance of fisheries, water, agriculture, flooded forest and biodiversity to maximize the provisioning, regulating and cultural services for the benefits of human well being and national economies. The sectoral governance zones-Tonle Sap's wetlands are classified into various zones to maximize its services. Naturally, Tonle Sap is classified into three ecological zones - the terrestrial ecological zone, the floodplain and the aquatic ecological zone. Each natural zone provides diverse ecosystem services. Economically, Tonle Sap has been classified into various functional and often conflicting zones since the French Protectorate. This dynamic notion of zoning helps understand the real wetland governance issues and problems that frequently relate to differing zoning conceptions of distinct agencies involved in resource governance [33]. Conservationally, under the biosphere reserve system, Tonle Sap is zoned into transitional, buffer and core zones [34]. Second, the fishery system has zoned the lake since the French control into three categories-commercial fishing, public or open access fishing and conservation. Third, recently, the flooded forest management system has classified the lake into three zones-zone 1 , zone 2 and zone 3 . The new and old zonings overlapped and conflicted, particularly the commercial fishing lots and the core zone of the biosphere reserves (Table 1). In 2012, the RGC abolished the commercial fishing area and returned it into the open access and conservation areas. Last but not the least, the area around Tonle Sap is farmed into sreleu, srekandal and srekrom.

\subsection{Regulating Services}

The Tonle Sap River acts as a key valve or artery connecting the Mekong River to the Lake, and thus, the authors cannot consider the Tonle Sap's biophysical characteristics without reference to the Mekong hydrological regime. First, the Tonle Sap Lake takes in a lot of water and helps reduce flooding in the Mekong River during the peak flood season and it releases water from the Lake to the Mekong River in the dry season helping to reduce salt intrusion in the Mekong Delta. Second, the Tonle Sap Lake is a key space for migratory fishes from the Lower Mekong Basin into the Lake system during the wet season and as a key space for fish production [20].

The Lake owes its uniqueness to the natural phenomenon of reverse water flow, with approximately half of an annual pulse absorbed by the Lake area from the Mekong River during the wet season (May to October) and released back during the dry season. This "flood pulse" has led one specialist, Anders Poulsen, to describe the Tonle Sap as "the pulsating heart" of the Mekong, and goes on to argue that "the flood pulse is what keeps the heart beating, if the heart stops, the system dies". It absorbs 20 per cent of the Mekong River's floodwaters and serves as a flood regulator $[22,35]$. The drop of the water level in the Mekong in the dry season creates the "reverse flow" from the Lake into the Mekong.

The Mekong has one flood pulse a year [19]. The volume of water flowing downstream floods the areas along the Mekong and the Mekong Delta in Cambodia and in Vietnam. As part of the Mekong River, the Tonle Sap Lake absorbs a volume of water from the Mekong River in the wet season, estimating at about $45 \mathrm{~km}^{3}$, which is about 10 percent of the Mekong water volume, reducing the flood in Mekong Delta in Cambodia below Phnom Penh and in Vietnam [15, 20]. Given the reduction of flood due to the existence of the Tonle Sap, the flooded area in the Mekong Delta in Vietnam is maintained between 1.2 and 1.4 million hectares [36]. However, under the high flood, 
the flooded areas in the Mekong Delta in Vietnam increase to 1.9 million hectares [37].

This creates a vast natural reservoir, where the Tonle Sap becomes a "bladder" of the Mekong basin, helping to reduce flooding downstream. Thus, the area along the Mekong, the Mekong Delta both in Cambodia and Vietnam is saved from flooding due to large volume of flood which is absorbed by the Tonle Sap Lake [17, 20].

Apart from absorbing water from the Mekong River in the wet season, the Tonle Sap Lake also releases water from the Lake to the Mekong River in the dry season and volume of water flow downstream to the Mekong Delta and to the China Sea. This happens due to the level of the Mekong water quickly drops to the point below the level of the Tonle Sap Lake and thus, creating a condition for water flowing from the Tonle Sap Lake to the Mekong and then continue to flow down to the China Sea. It subsides slowly until January and February and continues to gradually recede during March and April. Out-flow water from the floodplain and the lake increases the flow of water in the lower Mekong River, improving the condition of the Mekong estuary after saline intrusion during the dry period. The water released from this storage can also be used to irrigate the dry season crop in many parts of the Mekong delta. In this sense, the Tonle Sap Lake is considered by many Khmers to be the "backbone of their struggling nation's agricultural system".

The annual average outflow of the Tonle Sap Lake is estimated at about $78.6 \mathrm{~km}^{3}$. About $69 \mathrm{~km}^{3}$ ( $88 \%$ of outflow) from the Tonle Sap Lake returns to the Mekong River via the Tonle Sap River [15, 20]. The release of water from the Tonle Sap to the Mekong River during the dry season distributes water to the Mekong Delta. This water saves the Mekong Delta from salty intrusion. About 2.1 million hectares of the Mekong Delta are affected by the salinity during the dry season [37], and the volume of water from the Tonle Sap acts to reduce the intrusion of salty water into the mainland areas. Thus, Tonle Sap waters act as a natural flush helping to reduce salinity levels in the Delta, which may still be rising probably due to sea-incursions and long-term sea-level rise.

It plays an important role in determining fish productivity in the lake. The flow into the Tonle Sap Lake with a huge volume results in rising up water levels and changes water quality. These are key factors setting-off the migration of fish to spawn and feed in grounds located on the floodplains [38]. The flow stimulates the fish migration from as far away as Stung Treng and Kratie - in the upper Mekong River [30] and also brings fish from the Mekong to Tonle Sap. At the beginning of the wet season, as water rises, most fish species begin to spawn and as a result, huge numbers of larvae and juvenile fish from the Mekong come with the flow into the Tonle Sap Lake [27]. More than 200 billion fish fries and fingerlings are drifted down to the Mekong and the Tonle Sap Lake floodplain each year [39].

\subsection{Provisioning Services}

The flood pulse induces the zoning in the lake into the permanent lake. The areas that is flooded for six months and dry for another six months known as a floodplain and not flooded for the whole year or terrestrial area. These natural zonings make Tonle Sap productive and provide arrays of services for human, including agriculture, fisheries and biodiversity services $[18,21,38,40]$.

\subsubsection{Agricultural Services}

The terrestrial and floodplain areas form vast areas for agriculture that are highly productive. These can be classified as: sreleu (rainfed lowland rice fields), srekandal (medium deep water rice-fields) and srekrom (deep water rice fields/floating rice fields). Sreleu areas are named as such because they are located in the upper geographical area of the Tonle Sap floodplain, between eight and ten meters above sea level (m.a.s.1.) [38]. Rice cultivation in the sreleu areas is entirely dependent on rainfall, not on the 
lake's hydrology. Meanwhile, srekandal (medium deep water rice-fields) are located further inside the floodplain area and are lower in elevation than the sreleu, but higher than the srekrom. People have cultivated floating rice in this area in the past, but now cultivate "receding" rice, which follows the water as it recedes in the lake. Srekromare located furthest into the Tonle Sap floodplain. The rising water of Tonle Sap influences rice productivity levels in the srekrom. Thus, farmers cultivate rice varieties called sroveleungteuk (which titerally means rising water rice in English) that grow according to the water levels. In the dry season, farmers cultivate "dry season rice" in this area. Farming in these areas is carried out in a traditional way. It is small-scale and subsistence-based and largely dependent on rainfall but sometimes on water from Tonle Sap (Table 1).

On the one hand, farming in the sreleu, srekandal and srekrom areas are adversely affected if there is too much water in the wet season and too little in the dry season. Indeed, both these conditions leave farmers vulnerable. On the other hand, farming on the floodplain, particularly in srekrom and srekandal often are in conflicts with fishing activities and in the past, particularly with the fishing lots. Srekrom and sreleu are submerged by water from the Mekong for about six months of the year. Fisheries Administration claims that the areas that flooded by the Mekong water are considered as a fishery domain that Fisheries Administration (FiA) has authority over it. Hence, building dams, dikes, reservoirs, canals, ponds and reclaimed floodplain areas for agricultural purposes are not allowed inside the fisheries domain. The restrictions imposed by the fisheries sector have made agricultural development within the floodplain less developed and low productivity [41]. Some conflicts have occurred around the Tonle Sap Lake between farmers and fishers over the access to water for agriculture and fishing activities.

\subsubsection{Fisheries Services}

The lake is rich in fisheries. Freshwater fisheries represent one of the most important productive uses of wetlands in Cambodia in terms of economic benefits, livelihoods and nutrition and food security. These services have been commercialized via the increased control and exploitation of fisheries resources by the state for revenue generation. Historically, the lake was managed based on a commercial fishing system in which the French Protectorate transformed the lake into fishing lot system as the main governance system in 1908. Under this system, the fishing lots were auctioned out to private control and ownership.

The state had depended on fisheries as a major source of national revenue. Up until 1908, fisheries revenue contributed to 17 percent of national revenue for the French Protectorate Regime and by 1910, the incomes from fishing tax covered one-third of the administrative budget of the French Protectorate. Between 1999 and 2001, it is estimated that the inland freshwater fish catch was estimated at about 295,000-420,000 tons annually. About 60 percent of this catch came from a commercial fish catch in the Tonle Sap [30, 42], equivalent to about 235,000 tons. With an estimated annual inland fish production, the landing value of inland fisheries is estimated at about US\$150-200 million, but it increases to about US\$ 250-500 million in the marketing chain [30]. In comparison, the total monetary value of paddy rice in Cambodia is roughly $\$ 350-400$ million. This indicates the high dependence of the state on the "commercial space" as main source revenue for the national budget $[30,42]$.

In 1995, fisheries contributed to 3.2-7.4 percent of GDP. However, between 2002 and 2003, the contribution of fisheries to the GDP increased to about $11.7 \%$ [43]. After 2003, fisheries sector contribution to GDP increased to about $16 \%$ of GDP [44]. Thus, fisheries section plays an important role in a national economy and the Tonle Sap plays a vital role in the fisheries sector.

However, commercial fishing activities often conflicted with local fishing communities. Two sets of 
reforms were enacted in 2000 and in 2012. These reforms had led to cancel the fishing lot system and turned it into to an open access, conservation and community-based fisheries management area.

The cancellation of the fishing system has transformed the previously commercial fishing areas into public fishing areas. About 412,205 ha of public fishing area has been established into 175 community fisheries [33].

Apart from public fishing and community fishing areas, some areas of the Tonle Sap Lake are designated as "fish sanctuaries". There are eight fish sanctuaries, covering an area of 24,680 ha. The cancellation of fishing lots in 2012 has contributed to converting the fishing lots $(270,217 \mathrm{ha})$ and about 93,246 ha were transformed into 23 fish conservation areas.

\subsubsection{Biodiversity Services}

The Tonle Sap is also rich in biodiversity resources. About 500 inland fish species have been recorded in Cambodia and at least 280 species reside in the Tonle Sap [30, 45], classifying into 48 species of cyprinids, 7 species of Pangasidae, 5 species of Bagridae and 5 species of Siluridae, of which seven inland fish species identified in the Tonle Sap have a global significance. Some 42 reptile species are identified in the Tonle Sap, including one species endemic to the Tonle Sap-the Tonle Sap water snake Enhydrislongicauda. Nineteen global significance reptile species include two critically endangered and three listed as endangered species, seven turtles and a crocodile [41]. Apart from reptiles, the Tonle Sap is also home to some 225 birds species, of which $45 \%$ mainly the larger species [45].

People have used biodiversity resources for their foods and incomes. The increased population and increased development pressures have impacts on lake's biodiversity resources and thus, the governance of biodiversity resources in the Tonle Sap Lake stems from its importance as a refuge for globally rare and endangered species [28, 29, 45, 46]. King Norodom
Sihanouk proposed the Tonle Sap to be designated as a world heritage site in 1992, managed under UNESCO and in November 1993, a Royal Decree officially designated Tonle Sap as a multi-purpose protected area. Furthermore, another Royal Decree issued on 10th April 2001, designated Tonle Sap as a biosphere reserve [34].

Tonle Sap Biosphere Reserve is categorized into three zones: (i) a transitional zone; (ii) a buffer zone and (iii) a core zone. The core zone is further broken-down into three areas: (1) Prek Toal for bird colonies (21,342 ha); (2) Boeung Chmarfor bird breeding (14,560 ha) and (3) Stung Sen-a unique gallery forest $(6,355 \mathrm{ha})$ [47]. This situation has led to a new governance structure being formed in the reserve, which is managed by the Biosphere Reserve Secretariat (TSBRS) with technical and financial support coming from international organizations such as UNESCO. The transition zone is set up to promote management of the resources and human activities in Tonle Sap, reducing adverse impacts on the buffer and core zones of the lake. The buffer zone is used for research, management of the flooded forests, fisheries, agriculture, housing settlements and other land use activities - water resources, navigation, tourism and environmental preservation [34]. The core zone is designed as a national park or wildlife reserve [48].

\subsubsection{Flooded Forests}

Water from the Mekong River enters the Tonle Sap Lake, the level of which gradually rises before eventually submerging the surrounding forest for about six months. This flooded forest is important for both fish and people. About 175 fish species reside in the flooded forest around the Tonle Sap Lake [47]. The flooded forest provides good habitats for fish and the detritus left by the forest is a good source of nutrients for fish while the water is rising (Table 1).

The flooded forest areas had been declined from 791,000 ha in 2002 to 688,170 ha in 2005 [46, 49, 50]. Between 2005 and 2010, about 55,566 ha of flooded forest lost. At present, about 647,406 ha of flooded 
forest remain around the lake and it is protected by Decree issued in August 2011 [47].

In 2012, the Royal Government of Cambodia (RGC) made an effort to conserve the flood forest around the lake. They parceled the lake area into three zones [47]. Zone 1 -covering 417,451 ha-extends from national roads 5 and 6 down to the floodplain around the lake, which is largely covered by rice fields and human settlements. Zone 2-covering 365,300 ha-has a low human settlement density, few rice fields, more vegetation and natural ponds. Socio-economic activities in this zone are closely monitored and some activities are prohibited such as land ownership, which is subject to approvals from the local administration. Zone 3-covering 642,793 ha of largely flooded forest-protected by the sub-decree, was signed by Prime Minister Hun Sen and bans all human activities [47].

The Tonle Sap Authority (TSA) is the main state agency responsible for the management of the flooded forest and Tonle Sap as a whole. The flooded forest zoning system overlaps with the Biosphere Reserve areas. The Biosphere Reserve is managed under the authority of the Tonle Sap Biosphere Reserve Secretariat (TSBRS). The difference between them is that the Biosphere Reserve zones cover the whole lake, including the terrestrial areas, floodplains and aquatic areas. Whereas, the flooded forest zones only cover the flooded terrestrial areas and floodplains (Table 1).

\subsection{Cultural Services and Human Well-Being in Tonle Sap}

About 1.7 million live in the Tonle Sap Lake. They adapt to the hydrological change and live in close relation with the environment. Fishing villages in the Tonle Sap Lake are organized into three different groups situated in three different ecological zones-land-based village, water-based village and water-land based village [33, 50]. The "land-based villages" are located in areas between approximately 6 $\mathrm{m}$ above sea level (a.s.m.1.) [33, 51, 52]. Villagers are primarily engaged in farming with occasional fishing activities depending on water level [53-55]. The "water-based village" refers to the floating villages where local primarily rely upon fishing. Floating communities consists of many floating houses, which can be classified into four different types: boat houses, ferry floating houses, bamboo rafting floating houses and pen floating houses. The "water-land based villages" spend six months of the year on land and six months in water. In the wet season, the water floods the area around the village and surrounds the houses, which are built 6-8 meters above ground. Although fishing is a primary occupation, villagers also supplement their incomes through small-scale farming. These villages are in the ecological zone mostly affected by seasonal water level [33].

A total of 1,037 communities live around Tonle Sap. However, only 361 villages have been designated within the 175 community fisheries [33]. Approximately one third of households are dependent on fishing and members of the community fisheries are allowed to fish on a subsistent or small-scale [35]. The other two thirds of the lake residents (115 and 375 households) are permitted to fish in open access areas. Non-members of the fishing community are also permitted to fish in community fisheries or open access areas permitted they fish on a small-scale. Members of the community fisheries are also able to fish inside the open access areas [33].

A water-based community, like Peam Bang, floats on water in the Tonle Sap Lake year round. It is literally based on floating homes that make up a "floating community". Many water-based communities float and move from one location to another on water, for instance, Anlong Raing or Kampong Loung communities float and move approximately 5-7 km/year in distance. However, Peam Bang floats does not move [38]. In the peak flood season, the water-based community floats on water about 9-10 $\mathrm{m}$ above the sea level (a.s.m.l.). In the dry season, it floats on the water level about $1.5 \mathrm{~m}$ 
high. About more than $90 \%$ of households are engaged in fishing as a primary occupation and fishing is a main source of livelihoods, giving the fact that most of households own no farmland and never farm.

Unlike the water-based community, the land-water based community, like Kampong Phluk, is a community where people live six months on land and six months over water. The house is built on stilts about 6-8 $\mathrm{m}$ above the ground which could stand in water for six months without any effect. In the dry season, water recedes in the lake and the whole village is located on land. Thus, the community lives on land as with other normal land-based villages. However, in the wet season, the water flows into the lake and floods the village's areas around the village. The whole village is in water for six months and individual houses become "individual islands" [56-59]. The water level rises almost up to the house floor which is about 6-8 $\mathrm{m}$ high from the ground. The house is located in the same position all year, although the community experiences two extreme environmental conditions-flooding and drought conditions. Although the community is on land for six months, there is no land ownership in the land-water based community, as the areas around the community falls within the protected flooded forest. Thus, dwellers of land-water based community rely primarily on fishing as their primary occupation. About 90\%-95\% of households in land-water based community are engaged in fishing as a main source of livelihoods.

However, the land-based community, for instance, Kampong La, is a community where people settle on land and the rising Tonle Sap waters do not usually flood the village. It is located in higher areas between the area $6 \mathrm{~m}$ above sea level (a.s.m.1.) [51, 52]. People living in the land-based communities are engaged in farming and fishing, depending on how near the villages are located to the water body. They cultivate rice as a primary occupation and fishing is a secondary occupation to supplement their farming
[53-55]. In Kampong La, about 76 percent of households are engaged in farming as a "primary occupation" and they supplement their incomes by fishing. About 35 percent of households are engaged in fishing as a "part-time" occupation and nine percent of the total households are engaged in "full-time" fishing, as they are landless. Totally, about 44 percent of households, both with land and landless, are engaged in fishing.

\section{Conclusion}

The management of Tonle Sap's wetlands is centered on three sectors: biodiversity, fishery and agricultural water management. However, it does not adequately consider the social and environmental importance of the wetlands. The management is segmented and the governance is weak due to poor coordination among different agencies. In response to these issues, the Tonle Sap Authority (TSA) was established to improve coordination and strengthen the lake's governance.

The majority of Cambodia lies within the Lower Mekong Delta, making the MRC Agreement [60] highly relevant for the natural and political environment of the country. Improved relations and cooperation with MRC countries is crucial in resolving issues and reducing future conflict, such as those that arise around hydro-electric dams in Vietnam and Laos. The Cambodia National Mekong Committee (CNMC), established as a national are of MRC, is the coordinating body for all types of works related to the Mekong development. However, despite the large wetland areas around the Mekong, they do not work with wetland issues.

To improve effective governance, the ADB proposed to set up Tonle Sap Basin Management Organization (TSBMO), parallel with CNMC, to improve the coordination of work in Tonle Sap. However, in 2009, RGC instead established the TSA by a Royal Decree [43]. The TSA, established in 2009, is chaired by the Minister of Water Resources and 
Meteorology. Minister of MOWRAM also chairs the CNMC. This brings the MOWRAM, TSA and CNMC under one umbrella at a national level. Moreover, the Minister of MOWRAM is also a regional council member of MRC, improving water governance coordination in the Mekong and Tonle Sap regions. However, it MOWRAM mandate only address water and not wetlands. Thirty-one high level representatives from government ministries and institutions are appointed as members of the TSA. This improves stakeholder representation in the TSA and contributes towards an inclusive and deliberative decision-making process. However, the decision making process is largely the domain of government agencies and civil society representation is lacking.

At present, the government has involved communities and civil society organizations in the management of Tonle Sap. However, the top-down approach to decision making remains and communities and civil society are not involved in resolving conflict of determining access to fisheries groups. The government has taken strong measures to combat illegal fishing activities and the lower level government institutions have taken responsibility following the pressure from higher levels of government. The government has used the court system to combat illegal fishing and those found guilty, all small fishing operators were imprisoned [55]. Although this is a strong start by the Head of State, it is doubtful that this level of momentum will continue.

The provincial Department of Water Resources and Meteorology acts as a secretariat to the TSA. TSA commands are passed to the provincial department, which then implements the action. In Tonle Sap, TSA employed nine rangers across the lake to watch all activities and they are equipping with nine boats and other facilities. However, financially, they still face limited financial supports and therefore, their works have not been satisfactory.

The Department of Wetlands, within the MoE, is the state agency responsible for coordinating wetland management and ensures the integration of wetland issues into the management of fisheries, biodiversity, water and agriculture. The Department of Wetlands is working collaboratively with other government agencies and NGOs to promote the wetland institutionalization and community participation in wetland governance. All of these concerns need to be taken into account in considering the implications of multi-lateral environmental agreements (MEA) for wetland management in Tonle Sap. However, it is essential that wetlands are legally defined in the Cambodian context. At present, the lack of an overarching legal definition leaves each sector decide on their own.

Wetlands are yet to be clearly defined under Cambodian law and the lack of coherency is leading to confusion within sectors which are left to either develop their own wetland definition or none at all. Natural resource authority is segregated between territories and the legal ambiguity aggravates institutional conflicts and frustrates integrated management. The Fisheries Law leaves many resources unaccounted for, in particular, those may be considered non-fishery resources and does not provide a framework for ecosystem-based management beyond its role in fisheries production.

Institutional coordination for wetland management is weak, leading to competition among different institutions having mandates, roles and responsibly in Tonle Sap and overlapped initiatives. Although MoE leads wetland management decisions, many areas overlap with fisheries management. There is no clear coordination mechanism in place to facilitate this conflict and each agency will only work within their sectoral mandate.

There needs to be a legal mandate for the overall management and planning for wetlands at a national, regional and local level. Ramsar experience and guidance highlights the need take a multi-sectoral approach that involves civil society as well as the 
public and private sectors. A multi-institutional technical secretariat with decision-making authority, such as the one established under the sub-decree on Economic Land (industrial agriculture) Concessions 2005, is needed to effectively coordinate the management of wetlands.

The Governance of Tonle Sap and fisheries management is continuous changing, from the focus on commercial fisheries exploitation to community based fishery management and biodiversity conservation. Recently, the RGC terminated the 100-year old fishing lot system in the lake and returned the entire system to open access fishing and conservation that raises the concerns about the future of Tonle Sap. The change in the governance was rapid. Without any clear plan or strategy the national policy changes are not always translated into local action. Communities are still struggling to define their governing system and manage their water and fisheries. Water is a valuable resource and the conflict between rice irrigation and fishing is a continuing issue.

\section{Acknowledgments}

The author would like to thank and acknowledge the many interviewees who contributed to the research on wetland governance in Tonle Sap Lake. The author also gratefully acknowledges the many thoughtful and helpful comments provided by referee and anonymous referees, whose contributions helped to greatly improve this manuscript.

\section{References}

[1] Hall, B. 2007. Cambodia Sector Policy Assessment and MEA Commitments for Wetland Management. Synthesis report.

[2] Cowardin, L. M., Carte, V., Golet, F., and LaRoe, E. T. 1979. Classification of Wetlands and Deep Water Habitats of the United States. US: Interior Fish and Wildlife Service Office of Biological Services.

[3] Ramsar, Iran. 2005. "Resolution IX.1 Annex A: A Conceptual Framework for the Wise Use of Wetlands and the Maintenance of Their Ecological Character." In 9th Meeting of the Conference of the Parties to the
Convention on Wetlands. Accessed August 30, 2014. http://ramsar.rgis.ch/pdf/res/key_res_ix_01_annexa_e.pdf.

[4] Ritesh, K., Pierre, H., Randy, M. G., Sonali, S., Sellamuttu, S. T., and Nick, C. D. 2011. "Assessing Wetland Ecosystem Services and Poverty Inter-Linkages: A General Framework and Case Study." Hydrological Sciences Journal 56 (8): 1602-1621.

[5] Lebel, L., Anderies, J. M., Campbell, B., Folke, C., Hatfield-Dodds, S., and Hughes, T. P. 2006. "Governance and the Capacity to Manage Resilience in Regional Social-Ecological Systems." Ecology and Society 11 (1): 19.

[6] Ratner, B. D., Cohen, P., Barman, B., Mam, K., Nagoli, J., and Allison, E. H. 2013. "Governance of Aquatic Agricultural Systems: Analyzing Representation, Power and Accountability." Ecology and Society 18 (4): 59.

[7] Zheng, D., Mi, J., Ravesteijn, W., and Qiu, F. 2014. "Responsible Resource Management: the Predicament and Reform Path for Chinese Wetland Conservation." Wetlands Ecol. Manage 22: 509-521. doi:10.1007/s11273-014-9348-4.

[8] Millennium Ecosystem Assessment (MEA). 2005. Ecosystems and Human Well-Being: Wetlands and Water Synthesis. Washington, DC: World Resources Institute.

[9] Clare, S., Krogman, N., Foote, L., and Lemphers, N. 2011. "Where is the Avoidance in the Implementation of Wetland Law and Policy?" Wetlands Ecol. Manage 19: 165-182. doi: 10.1007/s11273-011-9209-3.

[10] Kotze, D. C. 2011. "The Application of a Framework for Assessing Ecological Condition and Sustainability of Use to Three Wetlands in Malawi." Wetlands Ecol. Manage 19: 507-520. doi:10.1007/s11273-011-9232-4.

[11] International Lake Environment Committee (ILEC). 2005. Managing Lakes and Their Basins for Sustainable Use: A Report for Lake Basin Managers and Stakeholders. Kusatsu, Japan: International Lake Environment Committee Foundation.

[12] Penny, D., Gordon, C., and Saingim, S. 2005. "Long-Term Rates of Sediment Accumulation in the Tonle Sap, Cambodia: A Treat to Ecosystem Health?" Journal of Paleolimnol 33: 95-103.

[13] Heinonen, U. 2004. Integrated and Socially Just Water Resource Management in the Lower Mekong River Region and Cambodia: How to Control Water Related Rural Push. Finland: Laboratory of Water Resources.

[14] Somony, T., and Schmidt, U. 2004. Aquatic Resource Management: Tonle Sap Great Lake. Phnom Penh: Department of Fisheries.

[15] Matsui, S., Keskinen, M., Sokhem, P., and Nakamura, M. 2005. "Tonle Sap: Experience and Lessons Learned Brief." International Waters: Science Database. Accessed March 21, 2015. http://www.worldlakes.org/uploads/ 
25_Lake_Tonle_Sap_27February2006.pdf.

[16] Kummu, M., and Sarkkula, J. 2008. "Impact of the Mekong River Flow Alteration on the Tonle Sap Flood Pulse." Journal of the Human Environment 37 (3): 185-192.

[17] Nikula, J. 2005. "The Lake and Its People.” M.Sc. thesis, Helsinki University of Technology.

[18] Junk, W., Baley, P. B., and Sparks, R. E. 1989. "The Flood Pulse Concept in River-Floodplain System." Canada's Special Publication in Fisheries and Aquatic Sciences 106: 110-127.

[19] Lamberts, D. 2001. Tonle Sap Fisheries: A Case Study on Floodplain Gillnet Fisheries. Bangkok: FAO Regional Officer for Asia and the Pacific.

[20] Kummu, M., Sarkkula, J., Koponen, J., and Nikula, J. 2006. "Ecosystem Management of the Tonle Sap Lake: An Integrated Modelling Approach." Water Res. Dev. 22 (3): 497-519.

[21] Lamberts, D. 2006. “The Tonle Sap Lake as a Productive Ecosystem." Water Res. Dev. 22 (3): 481-495.

[22] Mekong River Commission (MRC). 2003. State of the Basin Report. Phnom Penh: Mekong River Commission Secretariat (MRCs).

[23] Mak, S., Pheng, S., Khuon, K., Sin, C., Tes, S., and Chea, T. 2011. Profile of the Sub-Area Stung Treng (SA-6C). Phnom Penh: Cambodia National Mekong Committee.

[24] Sarkkula, J., Kiirikki, M., Koponen, J., and Kummu, M. 2003. Ecosystem Processes of the Tonle Sap Lake. Cambodia: Ecotone Ii-1 Workshop.

[25] Junk, W. 1997. The Central Amazon Floodplain: Ecology of a Pulsing System, Ecological Studies 126. Heidelberg: Springer Verlag.

[26] Rainboth, W. J. 1996. Fishes of the Cambodia Mekong. Rome: FAO Species Identification Field Guide for Fishery Purposes Fishes of the Cambodian Mekong.

[27] Poulsen, A., Poeu, O., Viravong, S., Suntornratana, U., and Thung, N. T. 2002. Fish Migrations of the Lower Mekong River Basin: Implication for Development, Planning and Environment Management. Phnom Penh: MRC Technical Paper.

[28] Campbell, I., Colin, P., Wim, G., and Valbo-Jorgensen, J. 2006. "Species Diversity and Ecology of Tonle Sap Great Lake, Cambodia." Journal of Aquatic Sciences 68 (3): 355-373.

[29] Bonheur, N., and Benjamin, D. L. 2002. "Natural Resource Management for Human Security in Cambodia's Tonle Sap Biosphere Reserve." Environmental Science and Policy 5: 33-41.

[30] Van, Zalinge, N., Thouk, N., Touch, S. T., and Deap. L. 2000. "Where Thereis Water, There is Fish?" In Common Property in the Mekong Issues of Sustainability and Subsistence, 37-50.
[31] Arias, M., Piman, T., Lauri, H., Cochrane, T., and Kummu, M. 2014. "Dams on Mekong Tributaries as Significant Contributors of Hydrological Alterations to the Tonle Sap Floodplain in Cambodia." Hydrology and Earth System Sciences Discussions 11 (2): 2177-2209.

[32] Grumbine, E. R., Dore, J., and Xu, J. 2012. "Mekong Hydropower: Drivers of Change and Governance Challenges." Frontiers in Ecology and Environment 10 (2): 91-98.

[33] Sithirith, M. 2011. "Political Geography of the Tonle Sap: Power, Space and Resources." Ph.D. dissertation, National University of Singapore.

[34] Royal Government of Cambodia (RGC). 2001. "Royal Degree on the Establishment and Management of the Tonle Sap Biosphere Reserve.” Accessed July 22, 2008. http://www.tsbred.org/docs/law_and_regulation/Royal_De cree_On_creation_and_managemet_of_tsbr_Eng.Pdf.

[35] Asian Development Bank (ADB). 2002. "Report and Recommendation of the President to the Board of Directors on a Proposed Loan and Technical Assistance Grant to the Kingdom of Cambodia for the Tonle Sap Environmental Management Project." Manila: Asian Development Bank (ADB). Accessed May 17, 2007. http://www.tsbr-ed.org/english/onlinecatalogue/textualdet ail.asp?ref.

[36] Kakonen, M. 2008. "Mekong Delta at Crossroads: More Adaptation or Control?" Ambio. 37 (3): 205-212.

[37] Tuan, L. A., Hoanh, C. T., Miller, F., and Sinh, B. T. 2007 "Flood and Salinity Management in the Mekong Delta, Vietnam." In Challenges to Sustainable Development in the Mekong Delta: Regional and National Policy Issue and Research Needs, edited by Thanh, B. T., Sinhand, B. T., and Miller, F. Bangkok: SEI.

[38] Sithirith, M., and Grundy-Warr, C. 2013. Floating Lives of the Tonle Sap. Thailand: Regional Center for Sustainable Development (RCSD).

[39] Thouk, N. 2009. "Community Fish Refuge Husbandry in Lowland Agriculture Ecosystem.” Doctoral thesis, Build Bright University.

[40] CNMC and Nedeco. 1998. Natural Resource-Based Development Strategy for the Tonle Sap Area, Cambodia. Final report.

[41] Degen, Peter and Thouk, Nao. 2000. "Historical, Cultural and Legal Perspectives on the Fishing Lot System in Cambodia." In Common Property in the Mekong: Issues of Sustainability and Subsistence, edited by Ahmed, M., and Hirsh, P. Penang: Australian Mekong Resources Center, Sydney University and World Fish Center.

[42] Ahmed, M., Hap, N., Vuthy, L., and Tiongo, M. 1998. Socio-Economic Assessment of Freshwater Capture Fisheries of Cambodia. Phnom Penh: Mekong River Commission. 
[43] Starr, P. 2003. "Fisheries Production in Cambodia." Catch and Culture 9 (1): 6-8.

[44] Van, Zalinge, N., Degen, P., Pongsri, C., Nuov, S., Jensen, J., and Nguyen, V. H. et al. 2004. "The Mekong River System." In Proceedings of the Second International Symposium on the Management of Large Rivers for Fisheries, edited by Welcomme, R. L., and Petr, T. Thailand: FAO Regional Office for Asia and the Pacific, Bangkok.

[45] Asian Development Bank (ADB). 2005. Cambodia: Establishment of the Tonle Sap Basin Management Organization. Final report.

[46] Tonle Sap Authority (TSA). 2011. White Book: Demarcation of Flooded Forest Area around Tonle Sap Lake. Phnom Penh: Ministry of Water Resources and Meteorology (MoWRAM).

[47] Royal Government of Cambodia (RGC). 2007. "Royal Decree on the Establishment of Tonle Sap Authority." Accessed June 12, 2008. http://www.foodsecurity.gov.kh/Otherdocs/Royal-Decreetsba-Eng.pdf.

[48] Asian Development Bank (ADB), Food and Agriculture Organization (FAO) and Fisheries Administration (DoF). 2003. General Fisheries Plan for the Management and Protection of the Tonle Sap, Tonle Sap Environmental Management Project. Phnom Penh, Cambodia: Fisheries Administration.

[49] Keskinen, M., Kummu, M., Salmivaara, A., Paradis, S., Lauri, H., and Moel, H. 2011. Baseline Results from Hydrological and Livelihood Analyses, Exploring Tonle Sap Futures Study. Finland: Aalto University.

[50] Keskinen, M. 2006. "The Lake with Floating Villages: Socioeconomic Analysis of the Tonle Sap Lake.” Journal of Water Resources Development 22 (3): 463-480.
[51] Keskinen, M. 2003. "Socio-Economic Survey of the Tonle Sap Lake, Cambodia." Master thesis, Helsinki University of Technology.

[52] Rab, M. A., Hap, N., Ahmed, M., Seng, K., and Viner, K. 2005. Socioeconomics and Values of Resources in Great Lake-Tonle Sap and Mekong - Bassac Area: Results from a Sample Survey in Kampong Chhnang, Siem Reap and Kandal Provinces. Penang, Malaysia: World Fish Center.

[53] Navy, H., Chuenpagdee, R., and Kurien, J. 2006. Livelihood Importance and Values of the Tonle Sap Lake Fisheries. Phnom Penh: Inland Fisheries Research and Development Institute, Fisheries Administration.

[54] Cambodia Development Resource Institute (CDRI). 2007. We Are Living With Worry All the Time-A Participatory Poverty Assessment of the Tonle Sap. Phnom Penh: CDRI.

[55] Asia Forest Network (AFN). 2004. Flooded Forests, Fish and Fishing Villages, Tonle Sap, Cambodia. Bohol, Philippines: AFN.

[56] Marschke, M. 2005. "Livelihoods in Context: Learning With Cambodian Fishers." Ph.D. dissertation, University of Manitoba.

[57] Marschke, M., and Berkes, F. 2005a. "Local Level Sustainability Planning for Livelihoods: A Cambodian Experience." International Journal of Sustainable Development \& World Ecology 12: 21-33.

[58] Marschke, M., and Berkes, F. 2005b. "Exploring Strategies That Build Livelihood Resilience: A Case from Cambodia." Ecology and Society 11 (1): 1.

[59] World Fish. 2013. Aquatic Agricultural System (AAS). The Tonle Sap Scoping report.

[60] Mekong River Commission (MRC). 1995. Agreement on the Cooperation for the Sustainable Development of the Mekong River Basin. Bangkok: Mekong River Commission Secretariat (MRCs). 